3 Research Square

\title{
The Economic Value of the Ecosystem Services of the Papenkuils Wetland - a Wetland in a Dryland
}

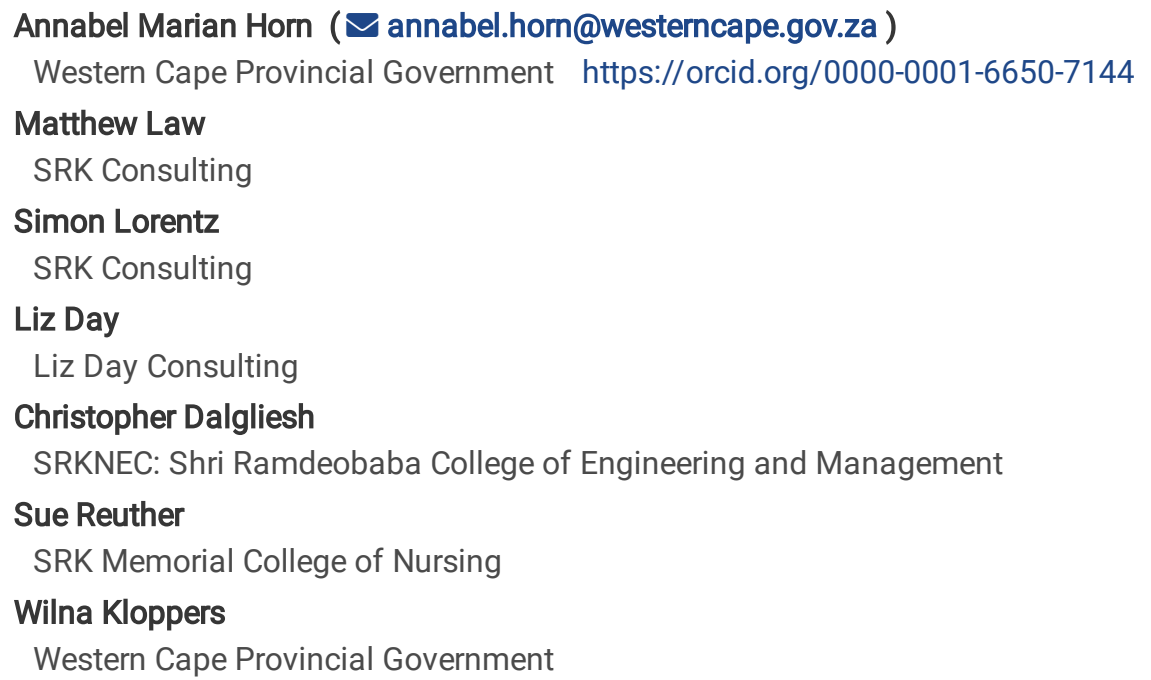

Keywords: Water isotopes, hydrology, ecosystem services, economic value

Posted Date: June 9th, 2021

DOI: https://doi.org/10.21203/rs.3.rs-540475/v1

License: (c) (i) This work is licensed under a Creative Commons Attribution 4.0 International License. Read Full License 


\section{Abstract}

The Wetlands in Drylands presented in this study focussed on the Papenkuils Wetland, which is in the Western Cape of South Africa, north of the Brandvlei Dam, and south west of Worcester, downstream of the confluence of the Breede (or Bree) and Smalblaar Rivers. This study sets out to establish the shadow price of the environmental services of this wetland, and to understand how this value changes with the possible future diversion of water to an agricultural dam before the Wetland, water provision to the wetlands. The study strongly recommends that the functionality of this wetland, as the largest in the Breede (Afrikaans word meaning wide) Catchment and with biodiversity that is recognised as an important remnant of habitats in the region, be maintained through management and sufficient inundation of water. This would be accompanied by a programme of abstraction for irrigation at a pumping station below the Papenkuils Wetland, as opposed to further abstraction of winter water above the wetland, as is currently proposed.

\section{Introduction}

Wetlands are life-giving systems, often providing valuable ecosystem services to people, while maintaining a wealth of biodiversity. Many wetlands contribute to water quality enhancement and reduce the impact of floods by distributing the force of the impact of water across their surfaces and peat-like soils. Despite the resilience of many wetlands, they are also vulnerable to direct, indirect and cumulative influences (Kotze et al. 2012). The demand for the monetary estimation of ecosystem services has been driven globally, established as a system of benefit transfer (Richardson et al 2015), partly as it is useful as a tool for establishing relative value in discussion with policy makers and stakeholders. The importance of the conservation of wetlands is placed in context by the assertion that up to $87 \%$ of the global wetland resource has been lost since 1700 and that wetlands are lost three times faster than natural forests (Ramsar 2015). In Africa, the sustainable management of wetlands is important for the continuing health, safety and welfare of many communities. Despite the importance of wetlands in Africa, economic and financial drivers, based on imperfect knowledge, are causing these wetlands to be modified or reclaimed. The ecosystem services of wetlands have an economic value to both local populations and to people living outside the wetlands (Schuyt 2004), which is often overlooked. In South Africa wetlands are recognised as one of the most threatened ecosystem types (Nel et al. 2011).

The natural vegetation of the study area of the Papenkuils Wetland is Cape Lowland Freshwater Wetland (Mucina \& Rutherford 2006), while the sandy areas support Breede Sand Fynbos. This wetland is the largest functioning wetland in the Breede River Valley, and one of the largest in the broader Western Cape region. The remaining portion of this wetland is $6.6 \mathrm{~km}$ long from west to east and $1.6 \mathrm{~km}$ wide from north to south. There is a high diversity of habitats within the Papenkuils Wetland, stemming from differences in topography, and water depth and distribution through the seasons, leading to an extraordinary diversity of plants and animals including bird life. There are also a number of botanical Species of Conservation Concern (SoCC) and plant species that provide sources of food and income for people, namely Aponogeton angustifolius (better known locally as waterblommetjies, where blom means flower in a local Dutch derivative language, Afrikaans).

The Papenkuils Wetland is an example of a wetland within a dryland, with an annual rainfall at the site of the wetlands of 200 to $400 \mathrm{~mm}$, while the Holsloot River arises in a mountainous area with an average annual rainfall of about $1200 \mathrm{~mm}$ (Schulze, Lynch 2006). In the aerial photographs of 1948 and 2019 (Figs. 1 and 2), the changes in the extent of the wetland can be clearly seen on the western side, with agricultural lands encroaching into the wetlands. The remnant Papenkuils Wetland remains an extensive functional and largely intact wetland of 982 hectares that provides valuable ecosystem services. The human impacts which have lowered the Present Ecological State (PES) of the wetland are upstream damming, river diversion, in-stream abstraction, groundwater abstraction, internal draining, grazing, agriculture and invasion by alien vegetation. It is proposed that the diversion weir to the Brandvlei Dam, on the Holsloot River upstream of the wetland be raised by $30 \mathrm{~cm}$ to increase the water available for irrigation, which would decrease the volume of winter water entering the Papenkuils Wetland (Basson \& Vonkeman 2018).

In this study the ecosystem services of the Papenkuils Wetland are valued through modelling, based on historical hydrological records and on the ground observations with drone photography and satellite coverage of both the hydrology of the wetlands systems and vegetation, with soil profiles, together with the tracking of the movements of water using isotopic analysis and water quality observations. The Papenkuils Wetland is found north of the Brandvlei Dam, and south west of Worcester, downstream of the confluence of the Breede and Smalblaar Rivers (Harding, 2003). The Holsloot River, regulated by the Stettynskloof Dam, drains into the Papenkuils Wetland, and water is directed from both the Holsloot River and the Smalblaar River into a canal to the Brandvlei Dam, where the water is used principally for agricultural irrigation. The key question once the value of the ecosystem services of the Papenkuils Wetland has been established is whether the raising of the diversion weir on the Holsloot River to enable additional water from winter rainfall, to flow to the

Page 2/20 
Brandvlei Dam for irrigation and away from the Papenkuils Wetland, would have an impact on the ecosystem services delivery and associated environmental costs of these wetlands.

The idea of ecosystem services clearly links the service to human well-being, and while the ecosystem functioning exists without the presence of people, the term is only used if there is a benefit to people, or demand for that service (Baleta 2020; Grossman 2012). This study ascertains the value of the Papenkuils Wetland and then considers whether a reduced influx of winter water would lessen the ecosystem services that are enjoyed by people. In establishing the Total Economic Value (TEV) of the study area, 1 ) the direct use value: both consumptive, such as the grazing of cattle, and non-consumptive, such as recreational value; 2 ) indirect use value, such as water quality enhancement; and 3) the non-use or intrinsic value is taken into account.

The ecosystem services which will be considered as benefits to people from the wetlands in this study are water storage, flood water attenuation and ground water recharge (Ameli \& Creed 2018; Turpie, Forsythe, Knowles, Blignaut, \& Letley, 2017); sediment retention by the wetlands (DWS 2017); grazing of agricultural stock; harvesting of resources; nutrient reduction, with concentrations decreasing at a point downstream of the Papenkuils Wetland (Cullis et al 2018); carbon sequestration at forty times more than terrestrial forests (Carnell et al., 2018); tourism and recreation; and intrinsic values.

\section{Methodology}

\section{Approach to the Study}

An initial assessment was carried out to identify key wetland features and functions and plant communities to characterise the ecosystem services. Extended winter rains meant that a late season assessment, commencing October 2020, still allowed for assessment of the wetland in its inundated condition. This was followed by dry season water and soil monitoring to understand the critical elements of the wetland.

Topographical surveys, water, nutrient and sediment inflows, surface and subsurface water and soil characteristics were assessed and flows through the wetland were compared against historic hydrological records and inundation imagery. The hydraulic and hydrology model was then used to estimate the impact on wetland functioning from changes to inflows. Ecosystem goods and services provided by the wetland were identified and characterised and an economic model was developed to estimate the environmental value of existing and future service levels of the wetland based on abstraction scenarios.

\section{Approach to the Valuation}

The annual Total Economic Valuation was modelled so that the environmental and social cost of additional winter water abstraction away from the Papenkuils Wetland could be estimated, as well as the shadow price per ML of this water. The team, guided by the literature, observed the ecosystem services of the wetlands that produce social well-being and economic value, and these were incorporated into the model. The findings for the hydrological model of the Papenkuils Wetland informed the economic model. The Nett Present Value (NPV) of the Baseline Abstraction Situation of water flow into the Papenkuils Wetland, and the NPV of the wetland under the abstracted flow taken over a 50 -year period is presented in this study in 2020 prices.

\section{Hydrology and Ecology}

Three transect lines (A to $\mathrm{C}$, with $\mathrm{A} 1$ to $\mathrm{A} 3$ representing the individual sites, and similarly for B1 to B11 and $\mathrm{C} 1$ to $\mathrm{C} 3$ ) were established for the assessment of wetland ecosystem, water quality and hydrological characteristics, as shown in the map of the Papenkuils Wetland. A is in the western, upstream area of the wetland with sites in the southern and northern branches of the Holsloot River, and the Breede River. B crosses large areas of dense Prionium serratum (palmiet), which influenced the location of the monitoring sites, through a variety of wetland habitats such as channels, shallow depressions and wetland flats (western sites, DWAF 2003). C (eastern downstream section) includes extensive wetland flats, and channelled flows, including the southern branch of the Holsloot River and the Breede River. Additional sites were also established, such as D1 and D2 in the Breede River downstream of the wetland, surrounded by wetlands disturbed by human activity.

\section{Water Levels}

The depth to the water table along transect B, was measured from piezometers every two weeks, using installed PVC pipes with slits in the lower one third of the pipes, such that the water equilibrates with the water table.

\section{Water Quality and Chemistry}

Page $3 / 20$ 
Calibrated meters were used to measure $\mathrm{pH}$, Electrical Conductivity (EC), temperature, dissolved oxygen (DO) and Oxidation-Reduction Potential (ORP) along transects A, B, C and at sampling sites at the inflow of the Holsloot River to, and outflow of the Holsloot River (before this river joins other rivers) from, the Papenkuils Wetland, as well as D1 and D2. Water samples were analysed for Nitrate nitrogen (NO3-N) and soluble reactive phosphorus (SRP) (PO4-P) concentrations using a HACH DR900 Multi-Parameter Colorimeter.

\section{Stable isotopes}

The ratio between heavier stable isotopes of water $\left({ }^{18} \mathrm{O}\right.$ or $\left.{ }^{2} \mathrm{H}\right)$ and the lighter isotope $\left({ }^{16} \mathrm{O}\right.$ or $\left.{ }^{1} \mathrm{H}\right)$, respectively, is used as a way of identifying the source of water, such as rainwater, upstream rivers, vadose zone water and ground water. The ratio $\left({ }^{18} \mathrm{O} /{ }^{16} \mathrm{O}\right.$ or $\left.{ }^{2} \mathrm{H} /{ }^{1} \mathrm{H}\right)$ is expressed relative to a standard (Vienna Standard Mean Ocean Water - VSMOW), with the result expressed as parts per thousand $\left(\delta^{18} \mathrm{O}\right.$ $(\%)$; and $\delta^{2} \mathrm{H}(\%)$ ). The position of the $\delta^{18} \mathrm{O}$ relative to the $\delta^{2} \mathrm{H}$ is known as the sample isotope signature.

As an example, if the source has been subjected to evaporation then there will be a higher abundance of heavier isotope ${ }^{18} \mathrm{O}$ or ${ }^{2} \mathrm{H}$, than the source prior to evaporation.

\section{Soil Profiles}

Soil profiles along Transect B were analysed for soil texture and colour as indicators of different wetland conditions. In order to inform the hydraulic model, samples were also sent to the Soil and Water laboratory of the Centre for Water Resources Research (CWRR), University of Kwa Zulu Natal (UKZN) to analyse particle size; water retention characteristics; and saturated hydraulic conductivity.

\section{Electrical Conductivity}

Probes for continuous monitoring (15 minute intervals), measuring Electrical Conductivity (EC), Water Pressure (WP - converted to water depth) and Temperature (T), WW5000-TDCS, were placed at sites reflecting the inflow of the Holsloot River to and outflow of the Holsloot River from the Papenkuils Wetland (as discussed above for Water Quality sampling). Data were downloaded from each site to a handheld Base Station and sent to the cloud via cellular phone connectivity.

\section{Soil Moisture}

Additional piezometers were installed to measure soil saturation percentages at roughly two weekly intervals, using a Sentek Diviner 2000 capacitance probe lowered into the piezometer, to take measurements at $100 \mathrm{~mm}$ depth intervals. Soil saturation percentage is calculated, by dividing soil water content by the maximum soil water content recorded under known saturated conditions.

\section{Catchment Runoff}

The Agricultural Catchments Research Unit (ACRU) model, working on a daily time step makes calculations on land use changes and the resultant water resource influences, was used for this study. This model is partitioned according to the water accounting method (Smithers \& Schulze, 1995). Water enters the top layer and then moves into the lower layers, as shown in Fig. 3.

The amount of rainfall (SAWS and DWS meteorological stations) and evaporation (daily A-pan evaporation records, DWS meteorological stations) drive the model in the contributing catchments, and all initial abstractions need to be considered such as depression storage and soil infiltration. The model includes a lag, between the rainfall entering the catchment and the storm water created leaving the catchment. The vegetation type with associated water use and soil cover with its leaf litter, and rooting depth with its effects on transpiration and water yield are also considered within the model (Schulze, Angus, Lynch, \& Smithers, 1995). Land use (South African National Land Cover 2018 (NLC2018) (GeoTerralmage, 2019)) needs to be taken into account in the model, as well as soil data (Agricultural Research Council's (ARC) Institute for Soil, Climate and Water) (ARC-ISCW, 1972-2002) and topography (United States Geological Survey, Shutter Radar Topography Mission (SRTM)).

The quaternary catchments, shown in Fig. 4, were used to get the initial climate data for the model and certain quaternary catchments were then subdivided to simulate daily volumetric discharge from the Stettynskloof Dam, the Smalblaar diversion into the Holsloot River, and the Holsloot diversion in turn into the Brandvlei Dam, and inputs into the Breede River from the Bothaspruit and Hartbees Rivers, extraction of water supply to Worcester and Rawsonville (39 Ml/day) and baseflow releases $(40 \mathrm{Ml} /$ day - although reduced to the observed flows of $10 \mathrm{Ml} /$ day from 1995 to 2005).

\section{Results}




\section{Changes in Surface Flows into the Papenkuils Wetland over time 1948 to present}

Using isotope signatures, satellite imagery observations, on-the-ground observations, and aerial photography dating to 1948 , it can be seen that the area to the west of the Papenkuils Wetland has changed through anthropogenically altered hydrology and the introduction of vineyards where the Holsloot and Smalblaar Rivers enter both the existing (2019 photograph) and original extent (1948 photograph) of these wetlands. As shown in the photographs, the Holsloot and the Smalblaar Rivers have been both straightened and bermed in sections, and much of the flow that would have entered the western wetland is instead diverted into the Breede River to the north.

The irrigation canals in the Central Breede Valley are set out in the map in Fig. 1 (Seeliger et al 2018) and for the purposes of this study the focus is on the irrigation canal important to this agricultural region that links the Holsloot and Smalblaar Rivers to the off-channel Brandvlei Dam (the Brandvlei Canal). This irrigation canal carrying the winter water to the Brandvlei Dam is upstream of the split into the northern and southern Holsloot, which occurs immediately upstream of the Papenkuils Wetland. The levels of the dam wall and canal mean that the canal can only fill the Brandvlei Dam to $73 \%$ capacity, after which the water flows along the Holsloot River into the Papenkuils Wetland (Western Cape Department of Agriculture 2018). The Smalblaar River delivers $44-48 \mathrm{~m}^{3} / \mathrm{s}$ flows to the Holsloot River, upstream of the Brandvlei irrigation canal, during the winter season, and at other times water from the Smalblaar River flows on to the Breede River, and then can also be transferred into the Brandvlei Dam at a pump station, just downstream of the Papenkuils Wetland.

On the western side of the extant Papenkuils Wetland, the berming of the northern branch of the Holsloot River results in the drying out of the north-west section of the wetlands. The berming of the southern branch of the Holsloot River on the western side of the Papenkuils Wetland, with the accompanying development of agricultural land results in the drying out of the wetlands below this section of the river. These changes have resulted in a reduction of braiding and alluvial fans as shown when comparing the aerial photographs of the Papenkuils Wetland of 1948 with that of approximately seventy years later in 2019 (Figs. 5 and 6).

\section{Sources of Water entering the Wetland}

From the isotope analysis and geo-spatial satellite imagery, as well as on-the-ground observation in this study, data has been collated showing the sources of water in the Papenkuils Wetland. Rainfall over the Papenkuils Wetland occurs mainly from May to September. There are also surface inflows from the Holsloot River, and the Breede River, while the Breede River has the tributaries of the Smalblaar, Bothaspruit and Hartbees Rivers, immediately upstream of the wetland. Water from the Brandvlei Dam enters the wetlands via artificial drainage trenches and there are irrigation return flows from agricultural areas surrounding the wetlands. Groundwater flows into the Papenkuils Wetland from the Rawsonville Aquifer and there are subsurface flows from the Breede River.

\section{Movement of Flows through the Wetland}

The assessment of the movement of water through the Papenkuils Wetland is based on the monitoring of soils and water levels. During the wet season, flows that are not diverted into the Brandvlei Canal from the Holsloot/ Smalblaar River (combined by a diversion from the Smalblaar to the Holsloot) pass into the southern and northern Holsloot channels (Fig. 4). The north west section will only be inundated with water in an extreme flood event, owing to the berm in place. In high flow conditions, water from the northern Holsloot and Breede River might feed the northern and north-eastern sections of the wetlands. The southern, south-western and south-eastern wetlands are fed through surface flows from the southern Holsloot, although the channel bed level of 232.20 mamsl needs to be exceeded for surface flows to pass within the channel. High flow conditions are needed for water to flow out of the channels to support the pools and seasonal depressions. The southern Holsloot channel is bermed for the first $\pm 1340 \mathrm{~m}$, but thereafter flows can pass into natural braids such that there are multiple discharge points into the wetlands. Further downstream, the southern Holsloot channel meanders and is joined by flows from the northern Holsloot and Breede Rivers, feeding the north east and eastern parts of the wetland. In the early wet season, before the diversion of water to the Brandvlei Canal, or when flows exceed canal capacity, water inundates the south-western, central and southeastern wetlands, giving rise to shallow wetland flats and pools. More permanent water in deeper channels and pools support stands of palmiet. The isotope date suggests that the southern Holsloot, and the north-eastern channels in the wetland are supported by the Rawsonville aquifer, which is in turn recharged from the Smalblaar and Holsloot Rivers. The Rawsonville aquifer is estimated to have a saturated thickness of 25m (Rosewarne 1981 in (Hay, Kotze, \& Breen, 2014)). The wetland depressions were dry by mid-summer, especially in the southern wetlands.

\section{Ecological Consequences of Model Outputs}

Page 5/20 
This portion of the results sets out the ecological consequences of the raising of the diversion canal to the Brandvlei Dam, from the Holsloot River, which has already received water from the Smalblaar River. The goal of the raising of the diversion canal to the Brandvlei Dam is for more winter water to be transferred to the Dam for irrigation, with a resultant loss to the Papenkuils Wetland. The loss of ecological functionality, with the associated loss of water to the wetlands will translate into a loss of ecosystem service levels, or value, which will be discussed further in this paper.

If the Holsloot Weir is raised by $30 \mathrm{~cm}$ to increase the diversion of winter water to the Brandvlei Dam it is considered that the hydroperiod of the Papenkuils Wetland would change such that 96 hectares of the extant wetland that is now seasonally or perennially inundated with water would no longer be inundated with water. This is more than $10 \%$ of the area of the extant wetland of this study. It is possible moreover that remaining wetland flats and shallow pools would dry out faster, and that some fauna (e.g. some frogs and nesting birds), will not have time to complete breeding cycles should this occur. Deep water pools would be the most resilient to this reduction in inundation, with flushing decreasing and gradually vegetation would fill in the pools. A reduction in wetland function also reduces the capacity of wetlands to filter water into groundwater to recharge the Rawsonville Alluvial Aquifer. The water in the wetlands themselves are used for livestock watering, without direct extraction of water. However, farmers in the broader Breede River Catchment extract water for irrigation from the Rawsonville Alluvial Aquifer. An expected transition to drier areas would be an increase in the unpalatable Seriphium plumosum (slangbos). Alien plants would possibly invade the areas where drying has created disturbances, with the resultant increases in alien clearing requirements.

Alternatively, if the berm on the north-western side of the northern Holsloot was punctured, and water allowed to channel through, then the 115 hectares on the western side of the Papenkuils Wetland would be more frequently inundated by water, improving wetland function and biodiversity. Grazing potential would improve as the Seriphium plumosum was replaced with more palatable species. Fire potential would decrease, and the wetland would be able to improve its capacity to store and release water slowly, allowing more sustained periods for pumping of water downstream of this wetland, to the Brandvlei Dam. Furthermore, the reduction of downstream flooding, through improved water storage and slow release from the wetland would reduce infrastructure damage downstream, such as the Le Chasseur diversion which is about $5 \mathrm{~km}$ downstream of the wetlands.

\section{Wetland Valuation of the Current (Baseline) and Two Future Abstraction Situations}

The nutrient reduction function is responsible for $90 \%$ of the environmental value of the wetland in this study over a future 35-year period. This total value has been estimated at R1200 million NPV, at a discount rate of $2.27 \%$, based on the ecosystem services of the Baseline Abstraction Situation as shown in Table 1. The hydrology model estimated an average inflow to the wetland of $87 \mathrm{Mm}^{3}$ per annum for the Baseline Abstraction Situation.

Table 1

Baseline Abstraction Situation environmental economic value

\begin{tabular}{|lll|}
\hline Ecosystem Service & Annual Average* & NPV: \\
\hline Flood abatement, groundwater recharge and sediment retention: & R311652 & R10 886603 \\
\hline Agricultural resource provisioning: & R2 671 047 & R64 029 985 \\
\hline Harvesting of natural resources: & R208 000 & R4 986 149 \\
\hline Nutrient reduction: & R44 239 108 & R1 059484563 \\
\hline Carbon sequestration: & R2 717 315 & R65 139 131 \\
\hline Tourism and recreation: & R134 386 & R3 221 491 \\
\hline Intrinsic value: & R6 455 & R154 727 \\
\hline Total in 2020 prices: & R50 287 962 & R1 207 902 650 \\
\hline
\end{tabular}

* Note: not discounted

If in the Modified Abstraction Situation 1 (Table 2), the Holsloot Weir is raised to divert more winter water into the Brandvlei Dam. The hydrology model estimated an average inflow to the wetland of $75 \mathrm{Mm} 3$ per annum for the Modified Abstraction Situation 1. This change in flow regime is estimated to reduce the NPV of the environmental services of the wetland to R1.06 billion over the 35-year period. 
Table 2

Modified Abstraction Situation 1, raising of the Holsloot Weir - environmental economic value

\begin{tabular}{|lll|}
\hline Ecosystem Service & Annual Average* & NPV: \\
\hline Flood abatement, groundwater recharge and sediment retention: & R293 166 & R10 239 675 \\
\hline Agricultural resource provisioning: & R2 448 065 & R59 357 685 \\
\hline Harvesting of natural resources: & R190636 & R4 622 307 \\
\hline Nutrient reduction: & R38 755 795 & R928 314 087 \\
\hline Carbon sequestration: & R2 490 669 & R60 390 095 \\
\hline Tourism and recreation: & R123 168 & R2 986417 \\
\hline Intrinsic value: & R5 916 & R143 437 \\
\hline Total in 2020 prices: & R44 307 414 & R1 066 053 704 \\
\hline
\end{tabular}

* Note: not discounted

The loss in environmental service value is approximately R6 million per annum due to the possible raising of the Holsloot Weir. The total discounted loss over the 35-year period is calculated as R 142 million NPV.

This has a shadow cost of lost value of estimated NPV of R326 per ML (it is estimated that an additional 435597 ML will be abstracted and diverted to the Brandvlei Dam, at an environmental cost of R142 million NPV = R326 per ML).

Under the Abstraction Situation 2, the enhanced channelisation of the northern Holsloot berms would result in an average additional 2 $\mathrm{Mm}^{3}$ over the Baseline Situation entering the wetland annually (or $89 \mathrm{Mm}^{3}$ ) and an increase in NPV to R1.24 billion over the 35-year period.

Table 3

Enhanced Abstraction Situation 2 - Recommended - Environmental Economic Value

\begin{tabular}{|lll|}
\hline Ecosystem Service & Annual Average* & NPV: \\
\hline Flood abatement, groundwater recharge and sediment retention: & R331589 & R11 584 350 \\
\hline Agricultural resource provisioning: & R2 937 139 & R69 568 215 \\
\hline Harvesting of natural resources: & R228 721 & R5 417 423 \\
\hline Nutrient reduction: & R45 240 849 & R1 083 364 201 \\
\hline Carbon sequestration: & R3 002 960 & R71 124 482 \\
\hline Tourism and recreation: & R147 774 & R3 500 132 \\
\hline Intrinsic value: & R7 098 & R168 110 \\
\hline Total in 2020 prices: & R51 896 130 & R1 244 726 912 \\
\hline
\end{tabular}

* Note: not discounted

The Enhanced Abstraction Situation 2 results in an NPV gain of nearly R37 million compared with the Baseline Abstraction Situation over the period. This gives an estimated NPV of R545 per ML (it is estimated that an additional $67588 \mathrm{ML}$ will be diverted to the wetland, with an environmental benefit of R37 million NPV = R545 per ML).

\section{Discussion}

Wetlands minimise flood damage through flow attenuation and enable groundwater recharge by their sponge-like nature of storing and slowly releasing water, and in this way also assist in the base flow in dry periods. This functionality of wetlands is seen to have both ecological and economic benefits, including for irrigation systems (Ameli \& Creed 2018; Turpie, Forsythe, Knowles, Blignaut, \& Letley 2017). Further aspects of ecosystem and service value considered in this study have been mentioned earlier in the paper, and this cumulative present value of costs and benefits needs to be adjusted using a social discount rate, where there is much debate in 
environmental resource economics circles around the level at which this rate should be set. People have a preference to receive money or benefit today, rather than in the future, and so future costs and benefits need to be discounted (London School of Economics, 2018).

\section{Social discount rate}

In the calculation of Net Present Value (NPV), taking future values into account the establishment of the size of the discount rate is debatable. According to the formula written below the higher the discount rate the lower the NPV. This implies that higher discount rates shift the burden of environmental damage to future generations and that lower values (costs) are given to future damages. The choosing of lower discount rates in NPV calculations makes current environmental conservation and restoration more worthwhile, rather than shifting this responsibility to future generations.

$N P V=F /\left[(1+r)^{\wedge} n\right]$ where, $N P V=$ Net Present Value, $F=$ Future payment (cash flow),

\section{$r=$ Discount rate, $n=$ the number of periods in the future}

So, the question is what discounting rate should be used? A survey of 200 experts by Drupp, Freeman, Groom, \& Nesj (2015) of The Grantham Research Institute on Climate Change and the Environment, established by the London School of Economics and Political Science established that over $90 \%$ of these experts accept a discount rate of between 1\% and 3\% (Drupp, Freeman, Groom, \& Nesj, 2015), with the mean discount rate of $2.27 \%$. Thus, a discount rate of $2.27 \%$ was used for this resource economics study. In the seminal paper of Weitzman (2001) a survey of experts showed that the modal accepted discounting rate was $2 \%$, so this value is in keeping with this original value. The time period (n) was taken as 35 years from present into the future for this study.

\section{Sediment Retention}

In the case of reduced wetland functionality, there will be less sediment retention. This can be from human activity and land use, including agriculture, leading to erosion of the wetland and sedimentation of downstream water channels. These have impacts which are direct, such as the blocking of irrigation, and indirect, such as the lessening of ecosystem service provision. There are associated economic costs with both these direct and indirect impacts. The hydrology model in this study has calculated that the Papenkuils Wetland retains 3500 tons of sediment and has a water and sediment storage capacity $68676 \mathrm{~m}^{3}$. Wetland storage volume is directly correlated with the inundated area, and the annual sediment retention is derived from the wetland storage volume.

\section{Grazing of stock}

The Papenkuils Wetland is owned by three farmers who graze cattle and to a lesser extent horses, reporting a carrying capacity of the wetland of one large stock unit (LSU) per 1.5 hectares.

\section{Harvesting of Resources}

Aponogeton distachyos (waterblommetjies) occur in water pools and are harvested by people from the local area. Water blommetjies in the flowering and fruiting stages are used to make soups and stews (Pemberton, 2000). The numbers of people collecting the Aponogeton spp or waterblommetjies varies between 6 and 12 per day for 6 months of the year at Papenkuils, with each harvester selling 25 bags per week at R40 per day in 2020 prices. Therefore, each harvester makes about R1000 per week (WRC (2014); Kotze (2020 personal communication) and Van der Merwe (2020 - personal communication).

\section{Nutrient Reduction}

The increase in population in the Breede has led to increased nutrient load, which is inadequately treated by the Wastewater Treatment Works in the Breede Catchment, as well as nutrient load input from agriculture (Cullis et al, 2018). The wetland has an important ecosystem service function in the reduction of nutrient load, through plant and soil uptake and denitrification. The nitrogen and phosphorus levels are above the irrigation guidelines in this part of the Breede River, decreasing downstream of the water offtake to the Brandvlei Dam and Papenkuils Wetland, and increasing further downstream of the town of Robertson (Cullis et al, 2018). This does seem to indicate the important role that this wetland plays in nutrient reduction. This study estimates that the Papenkuils Wetland reduces the nutrient load by 154 tons per annum. While the bulk water supply of Worcester, the major town in the area is directly from dams, the agricultural sector, using $90 \%$ of water in the Breede Catchment (Western Cape Government, 2018) directly benefit from this reduction of nutrients in their use of run of the river water. A direct correlation will be a reduction in algal growth, which blocks irrigation pipes (De Lange et al, 2016).

\section{Carbon Sequestration}


The level of carbon in the atmosphere in the form of carbon dioxide plays an important role in global climate, with higher levels causing global warming. Wetlands store carbon, are known as an efficient carbon sink and can exchange carbon with the atmosphere: if wetlands are degraded they will release carbon to the atmosphere. A reduction of water supply to the wetlands would have this effect. This study estimates that the Papenkuils Wetland currently stores an average of 96786 tons of carbon in organic soil, equating to 355205 tons of atmospheric $\mathrm{CO}_{2}$, with an estimated annual value of R2 717315 and an NPV of R65 million.

In the Modified Abstraction Situation 1 with the raising of the Holsloot Weir and increased diversion of winter water to the Brandvlei Dam, the wetland would store an average of 8000 tons less organic carbon, with an average annual cost of R225 000 in 2020 costs of possible climatic changes. The Enhanced Abstraction Situation 2 is recommended, and the wetland would increase its average stored carbon from 96786 to 106960 tons, with an NPV of R71 million (i.e. a benefit of R6 million over the 35-year period in 2020 prices). This is the national social cost (benefit) of carbon, which is often expressed as a monetary value per ton (Ricke, Drouet, Caldeira, \& Tavoni, 2018) (in this case, R663 per ton). A study by Nordhaus (2017) estimated the global social cost of carbon to be US $\$ 31$ per ton of $\mathrm{CO}_{2}$.

\section{Tourism and Recreation}

Tourism often centres around rivers and wetlands, drawing people to an area, where they will spend money on activities in the area and nights in accommodation. Based on a spatial analysis of geo-referenced photographs taken in the district municipality, this study estimated that up to $40 \%$ of the total tourism spend on natural attractions was on attractions in proximity to freshwater resources. While the Papenkuils Wetland has the capacity to be further developed for tourists, it is not currently recognized as a tourism attraction (and therefore demand for this service is considered to be low in the economic model). Nevertheless, the potential tourism value of the wetland would decrease if the winter water flows to the wetlands were diverted.

\section{Intrinsic Value of the Wetlands}

In economic terms, people gain utility from knowing that an ecologically important or beautiful wetland or other natural area is intact and conserved, even if they do not visit this area or benefit directly or indirectly (Snaddon, Dietrich, Forsythe, \& Turpie, 2018). In other words, joy is derived from this knowledge alone.

\section{Papenkuils Wetland Valuation Model}

The current condition or baseline of the Papenkuils Wetlands storage capacity has been estimated at $68676 \mathrm{~m}^{3}$, with a retention of 3554 tons of sediment. In this study the replacement cost of the water storage, flood attenuation and groundwater recharge functions of the wetland were estimated based on the capital and operational costs of a dam with the same volume. According to Snaddon et al, 2018, and corrected for 2020 prices, this dam would have an annualised capital cost (CAPEX) of R4.51/ $\mathrm{m}^{3}$ per annum.

The annual operational cost is assumed to be the lower range of the estimated operational and maintenance (O\&M or OPEX) costs for dams in Australia by Pertheram \& McMahoon (2019) at $0.14 \%$ of the lowest initial capital costs realized in Australia (calculated as R20 / $\mathrm{m}^{3}$ in this 2019 study, corrected for 2020 prices).

In this study it is assumed that flood abatement, flow regulation, groundwater recharge and sediment retention are fully demanded in the catchment, as this is part of the definition of ecosystem services. Using this replacement cost method described above, these functions of the Papenkuils Wetland are valued at R311 609 per annum in 2020 prices, as the baseline value.

Under the Modified Abstraction Situation 1, with a possible further diversion of winter water to the Brandvlei Dam, the storage capacity of the Papenkuils Wetland would decrease by $6 \%$ from $68676 \mathrm{~m}^{3}$ to $64579 \mathrm{~m}^{3}$, with an annual loss in ecosystem service value of these functions of R18 500.

Under the recommended Enhanced Abstraction Situation 2, an annual increase in the value of the water storage, flood attenuation and groundwater recharge functions of R20 000 in 2020 prices can be anticipated, linked to a $6.5 \%$ increase in volume of storage capacity of the wetland. This would somewhat offset the benefit of increased agricultural production through the diversion of additional winter water to the Brandvlei Dam and supports the proposition that water should rather be extracted from the Breede River for the Brandvlei Dam below the Papenkuils Wetlands.

The method for valuing the stock grazing on the land was determined by the annual value of the livestock grazing the wetland (based on Turpie et al 2017). At an estimated demand of $50 \%$ of the wetland area for grazing, the worth of this ecosystem service was estimated to be R2.5 million per annum in 2020 prices. This value was $8 \%$, or R220 000, lower under the Modified Abstraction Situation 1, and increased by $11 \%$ or R265 000 in 2020 prices under the recommended Enhanced Abstraction Situation 2.

Page 9/20 
It is considered that the current total annual value of the harvesting of Aponogeton spp or waterblommetjies by the local community is R208 000 at 2020 prices. This would decrease by $8 \%$ or R17 000 annually in 2020 prices with the raising of the Holsloot Weir, diverting winter water to the Brandvlei Dam. The value to the local community would increase by $11 \%$ or R17 000 annually in 2020 prices under the recommended Enhanced Abstraction Situation 2.

The nutrient reduction of the wetlands was calculated as a replacement cost equivalent the construction and annual electricity consumption of an Anion IX Water Treatment plant, using a cost equation (Eq. 1) derived from a Water Management Tool from AQWATEC(2010) for the three abstraction situations in this study. Nutrient recoverability of $80 \%$ for the plant is assumed.

Equation 1:

CAPEX (R million $)=\mathrm{cV}^{\mathrm{a}} \times \mathrm{V} \times$ Average CPI since $2010 \times \$ / \mathrm{R}$ Exchange Rate

where: $\mathrm{a}=-0.21$ (plant specific exponent for AQWATEC model)

$c=0.652239683$ (plant specific factor for AQWATEC model)

$V=$ Flows into wetland (ML per annum) / 3.785 (factor aligning the inflow to the AQWATEC model gallons unit)

This CAPEX in the study was payable as a loan over 35 years at South Africa's prime interest rate.

Operational costs included in the model were limited to the average electricity consumption of an Anion IX plant, at South Africa's electricity rate to large industrial consumers in 2020 (R0.70 per kWh).

The findings in this study were that under current flow conditions into the Papenkuils Wetlands, maximum daily throughput is $473 \mathrm{ML}$. Assuming 50\% demand for this service, the cost of a water treatment plant of a capacity to replace this wetland service is R440 million, with an annual cost of R33 million over the 35-year period. This facility would abstract an average of 154 tons of nutrients per annum under the current flow regime.

Under the Modified Abstraction Situation 1, the wetland would have a maximum daily throughput of $403 \mathrm{ML}$. Assuming $50 \%$ demand for this service, the cost of a water treatment plant of a capacity to replace this modified wetland service is R387 million, with an annual cost of R25 million over the 35-year period. This facility would abstract an average of 152 tons of nutrients per annum under the current flow regime, 2 tons less per annum of nutrients than would be assimilated, with an environmental cost of R5.5 million per annum to downstream users in 2020 prices. Under the Modified Abstraction Situation 1, which is the recommended enhanced abstraction scenario, maximum daily throughput will increase marginally but the assimilation of nutrients will be the same as for the current flow, namely 154 tons.

The intrinsic value of the wetland was extrapolated from the valuation of the Fynbos Biome by Turpie (2003) which was based on a willingness to pay contingent valuation survey, adjusted for the current extent of the biome, updated to 2020 prices. While this extrapolated value of R11 per ha is extremely low it is used as a proxy in this study, acknowledging that a new, site specific, stated preference estimation of the intrinsic value of this highly conservation worthy wetland would likely yield higher non-use values.

It is further noted that observed preferences or use is considered a more reliable methodology for the understanding of people's valuation of nature. This study suggests a value of up to R850 000 per annum for the wetland for its potential future development as a tourism resource.

Under the baseline, or current abstraction situation, ecosystem services of the Papenkuils Wetland generated an average of R50 million of environmental value per year in 2020 prices, which is a marginal value of R85 000 per hectare. With the discount rate of $2.27 \%$, the wetland is estimated to generate environmental value with an NPV of R1.2 billion over the 35-year period, with about $90 \%$ of this value generated by the nutrient reduction function (see Table 1).

The NPV of wetland services reduces by R142 million over the 35-year period to R1.066 billion under the Modified Abstraction Situation 1 of the Raising of the Holsloot Weir with increased diversion of winter water to the Brandvlei Dam (see Table 2). The increased diversion results in an average $12446 \mathrm{ML}$ reduction of surface water flows into the Papenkuils Wetland, equating to an average environmental cost of R481 per ML in 2020 prices. The additional water abstraction (diversion) over the 35-year period is modelled to be $435597 \mathrm{ML}$, with a discounted environmental cost of R326 per ML (see Table 4).

Page $10 / 20$ 
For the recommended Enhanced Abstraction Situation 2, an additional annual average of $1931 \mathrm{ML}$ of water would enter the wetland, with an increased NPV from the Baseline Abstraction Situation of R1.24 billion over the 35 year period (a benefit of R36 million NPV over the baseline).

Under this scenario the wetland is modelled to generate an average of R52 million in environmental value per year in 2020 prices. With the discount rate of $2.27 \%$, the wetland is estimated to generate environmental value with a NPV of R1.24 billion under this situation over the 35-year period (a benefit of R36 million NPV). The reduced diversion results in an average $1931 \mathrm{ML}$ increase of surface water flows into the Papenkuils Wetland, equating to an average environmental benefit of R833 per ML in 2020 prices. The additional water entering the wetland over the 35-year period is modelled to be $67588 \mathrm{ML}$, with a discounted environmental cost of R545 per ML (see Table 5).

Table 4

Environmental Cost of Modified Abstraction Situation 1 Per ML

\begin{tabular}{|lll|}
\hline Ecosystem Service & Annual Average* & NPV: \\
\hline Additional water abstraction (ML): & 12446 & 435597 (total) \\
\hline Baseline environmental value: & R50 287962 & R1 207902 650 \\
\hline Modified Abstraction Situation 1 environmental value: & R44 307 414 & R1 066 053 704 \\
\hline Environmental cost of additional water abstracted: & R5 980 548 & R141 848946 \\
\hline Environmental cost of water abstraction per ML: & R481 & R326 \\
\hline
\end{tabular}

Table 5

Environmental Value Add of Enhanced Abstraction Situation 2 Per ML

\begin{tabular}{|lll|}
\hline Ecosystem Service & Annual Average* & NPV: \\
\hline Additional water entering wetland (ML): & 1931 & 67588 \\
\hline Baseline environmental value: & R50287962 & R1 207902650 \\
\hline Enhanced Abstraction Situation 2 environmental value: & R51 896130 & R1 244726912 \\
\hline Environmental value add from additional water entering wetland: & R1 608 168 & R36 824262 \\
\hline Environmental benefit of reduced water abstraction per ML: & R833 & R545 \\
\hline
\end{tabular}

\section{Recommendations For Improving The Functioning Of The Papenkuils Wetland}

The Papenkuils Wetland has importance owing to its size as the largest wetland in the Breede Catchment, its biodiversity, and ecosystem services. As such its conservation is important. Its biodiversity includes several plant species of conservation concern, and the wetland supports up to $30 \%$ of the global population of some of these species. The wetland has been improved since the early 2000 s through alien clearing, which has reduced abstraction of water by alien plants through transpiration, as well as conserving natural plant communities. The alien clearing has been carried out through public private partnerships between the local land owners and organisations such as Working for Water and Working for Wetlands, while considerable improvement is required for the municipal section on the eastern side, which was not included in the extant of functional wetland for this study. This is especially recommended in the light of the need to reduce the impact of Climate Change.

In summary it is recommended that the following be considered for the Papenkuils Wetland:

- Improve the storage capacity of the wetland, as set out below, to enable better wetland functioning and a higher proportion of flows to be abstracted downstream of the Nekkies Bridge and pumped into the Brandvlei Dam.

- Ensure that the southern Holsloot channel receives enough water to maintain wetland function.

- Adjust the Brandvlei Canal diversion from the Holsloot River Weir so that the southern Holsloot channel can be breached beyond the end of the berm (see Fig. 6) to spread water to the surrounding wetlands.

- Inundate the wetlands as a whole to a level of $199 \mathrm{~m}$ above mean sea level, three to five times a year.

- Flush the pools and channels of the Northern Holsloot periodically. 
- Allow water to breach the northern berm and inundate the droughted Western section of the Papenkuils Wetland periodically to rehabilitate 115 ha of the wetland and improve storage capacity.

- Continue alien clearing in the Papenkuils Wetland, with attention to the municipal section to the east of the wetlands, outside of the functional extant of the wetlands of this study.

- Maintain the areas of the wetlands that have been cleared to prevent further spread of alien plants.

\section{Conclusions}

A key aim of this study was to improve understanding of the hydrological flows in the Papenkuils Wetlands, as a key driver of ecological function so that policy makers are informed in their decisions about flow allocations from the Holsloot River system. The Papenkuils Wetland is the largest intact and functioning wetland in the Breede Valley at 982 hectares and as such, given the diversity and value of ecosystem services discussed in this paper, it is worth conserving at its present size and biodiversity. There are several plants of conservation concern in this wetland with good representation.

Isotopic and geospatial analysis and photographic evidence over time, together with ground truthing, has shown that this wetland has already been reduced in size through agricultural activity, and its hydrological flows altered through berming, such that water no longer reaches certain sections of the wetland as it originally did. Inundation of the Papenkuils Wetland is reduced by preferential channelling of winter water into the Brandvlei Dam, preferential channelling of water to the northern arm away from the braiding of the southern Holsloot arm and the berm that blocks the flow from the Northern Holsloot into the northwest section of the Papenkuils Wetland.

The Modified Abstraction Situation 1 reduces the frequency of diversion rates below $1 \mathrm{Mm}^{3} /$ day, although it increases diversion greater than $1 \mathrm{Mm}^{3} /$ day. The Enhanced Abstraction Situation 2 diversions are also more than the baseline (current), but include diversions of 3.2 $\mathrm{M}^{3} /$ day, while other high flow diversions are of lower frequency than in the Modified Abstraction Situation 1. Reasons for these flow differences are found in the governance rules set for each. The further diversion of winter water by the raising of the Brandvlei Canal would have a significant impact especially on the inundation of the southern area of the wetland, where only the deepest pools surrounded by Prionium serratum (palmiet) would remain. Broadly, there would be a decline in the wetland area, as the channels would be overtopped in winter flood events far less often. This would reduce the plant biodiversity, and fauna where their breeding life cycles are affected by shorter hydroperiods.

The raising of the Brandvlei Canal would trigger Section 21c and 21i water uses in the National Water Act 36 of 1998 (NWA), and thus require Water Use Authorisation, as well as Environmental Authorisation in terms of the National Environmental Management Act 107 of 1998.

This study showed that the NPV of the environmental services is estimated to be R 1200 million over a chosen 35 year period, which is expected to reduce to R1 060 million over the same period if the Holsloot Weir is raised so that additional winter water is diverted to the Brandvlei Dam. The NPV of environmental services could increase to R1 240 million over the next 35 years if the Enhanced Abstraction Situation 2 discussed in this paper were to be followed. This represents an enhancement of the environmental value of the Papenkuils Wetland and the associated increase in environmental services to people.

\section{Declarations}

\section{Acknowledgements}

Funding for the study was provided by the Department of Environmental Affairs and Development Planning (DEA\&DP), Western Cape Government, South Africa. SRK was appointed by DEA\&DP for this study. Maps produced by Sub-Directorate Spatial Information Management, DEA\&DP, Western Cape Government.

\section{References}

1. Ameli A, Creed I (2018) Groundwaters at Risk: Wetland Loss Changes Sources, Lengthens Pathways, and Decelerates Rejuvenation of Groundwater Resources. Journal of the American Water Resources Association

2. AQWATEC (2010) Produced Water Treatment and Beneficial Use Information Centre. Retrieved March 2021, from The Advanced Water Technology Center: http://aqwatec.mines.edu/

3. ARC-ISCW (1972-2002) Land Type Survey Staff conducted from 1972 to 2002. Pretoria

Page $12 / 20$ 
4. Baleta H, Tien S (2020) Setting Site Water Targets Informed by Catchment Context, CASE STUDY: Upper Vaal River Basin and Berg and Breede River Basins, South Africa. United Nations Global Compact CEO Water Mandate and Pacific Institute

5. Basson G, Vonkeman J (2018) Hydraulic design aspects of the proposed Holsloot-Brandvlei Dam Diversion upgrade in the Western Cape. SANCOLD 2018 Conference: Sustainable Dam Engineering in an ever-changing world. Retrieved October 2020, from https://www.researchgate.net/publication/328836910_Hydraulic_Design_Aspects_Of_The_Proposed_HolslootBrandvlei_Dam_Diversion_Upgrade_In_The_Western Cape

6. Carnell PE, Windecker SM, Brenker M, Baldock J, Masque P, Brunt K, Macreadie P (2018) Carbon stocks, sequestration, and emissions of wetlands in south eastern Australia. Global Change Biology

7. Cullis J, Rossouw N, du Toit G, Petrie D, Wolfaardt G, de Clercq W, Horn A (2018) Economic risks due to declining water quality in the Breede River catchment. Water SA, 44

8. De Lange WJ, Botha AM, Oberholster PJ (2016) Towards tradable permits for filamentous green algae pollution. J Environ Manage 179:21-30

9. Department Water Affairs \& Forestry (DWAF) (2003) Papenkuils Wetland: Intermediate (Ecological) Reserve Determination. Prepared by W.R. Harding of Southern Waters Ecological Research and Consulting as part of the Breede River Basin Study. DWAF Report No $\mathrm{PH} / 00 / 00 / 1402$

10. Department of Water and Sanitation (DWS) (2017) Determination of Water Resources Classes and Resource Quality Objectives for the Water Resources in the Breede-Gouritz Water Management Area: Status Quo. Retrieved February 2021, from http://www.dwa.gov.za/rdm/WRCS/doc/Status\%20Quo\%20Report\%20final\%20small_final.pdf

11. Drupp M, Freeman M, Groom B, Nesj F (2015) Discounting disentangled. Centre for Climate Change Economics and Policy. Retrieved February 2021, from https://www.Ise.ac.uk/Granthamlnstitute/wp-content/uploads/2015/06/Working-Paper-172-Drupp-et-al.pdf

12. GeoTerralmage (2019) DEA E1434 Land-Cover: South African National Land-Cover 2018 Report and Associated GeoTiff Datasets. South Africa

13. Grossman M (2012) Economic value of the nutrient retention function of restored floodplain wetlands in the Elbe River Basin. Ecological Economics, pp 108-117

14. Harding W (2003) Papenkuils Wetland Intermediate (Ecological) Reserve Determination. Retrieved May 2020, from https://saeis.saeon.ac.za/Archive/Literature/Reports/RDM/Papenkuils\%20Wetland\%20RDM_2003.pdf

15. Hay D, Kotze D, Breen C (2014) Livelihoods and Wetlands: Restoration of wetland social-ecological processes to sustain the ecosystem services necessary to support livelihoods. The Papenkuils Wetland: A Case Study from the Western Cape. A Foundation for the Well-Wet Toolkit. WRC K5/1986.1

16. Kienzle S, Flügel WA. The salinity of the Breede River and its tributaries between Brandvlei dam and H5M04: Summary of daily data up to September 1987. Pretoria: Hydrological Research Institute: Breede River Research

17. Programme (BRSRP), Department of Water Affairs; 1988

18. Kotze DC, Ellery WN, Macfarlane DM, Jewitt GPW (2012) A rapid assessment method for coupling anthropogenic stressors and wetland ecological condition. Ecol Indic 13:284-293. https://doi.org/10.1016/j.ecolind.2011.06.023

19. Kotze D (2018) Case Study: Testing the draft set of Wetland PES (Present Ecological State) tools on the Papenkuils Wetland in the Breede Catchment. Appendix 3 in Ollis, D., Macfarlane, D., Kotze, D. and Ngobela, T. Deliverable \#5: WRC K5/2549

20. London School of Economics (2018) What are social discount rates? Retrieved February 2021, from https://www.Ise.ac.uk/granthaminstitute/explainers/what-are-social-discount-rates/

21. Mucina L, Rutherford M (2006) Vegetation map of South Africa, Lesotho, and Swaziland. Strelitzia 19. South African National Biodiversity Institute, Pretoria

22. Nel JL, Murray KM, Maherry A, Petersen CP, Roux DJ, Driver A, Hill L, Van Deventer H, Funke N, Swartz ER, Smith-Adao LB, Mnona N, Downsborough L, Nienaber S (2011) Technical Report for the National Freshwater Ecosystem Priority Areas project. WRC Report No. 1801/2/11. Water Research Commission, Pretoria

23. Nordhaus D (2017) Revisiting the social cost of carbon. PNAS, 114(7), 1518-1523. Retrieved February 2021, from https://www.pnas.org/content/pnas/114/7/1518.full.pdf

24. Pemberton R (2000) Waterblommetjie (Aponogeton Distachyos, Aponogetonaceae), a Recently Domesticated Aquatic Food Crop in Cape South Africa with Unusual Origins. In: April- June). Economic Botany, pp 144-149

25. Pertheram T, McMahoon T (2019) Dams, dam costs and damnable cost overruns. Journal of Hydrology, 10. Retrieved February 2021, from https://reader.elsevier.com/reader/sd/pii/S2589915519300100?

Page $13 / 20$ 
token=92227C871D935111C9DCE6317D7F1A8ED19025375B1E49E6CBEAD6E4FEBB8B56F1630B593E469530732977C2A8FFCF41

26. Richardson L, Loomis J, Kroeger T, Casey F (2015) The role of benefit transfer in ecosystem service valuation. Ecol Econ 115:51-58

27. Ricke K, Drouet L, Caldeira K, Tavoni M (2018) Country-level social cost of carbon. Nature Climate Change

28. Ramsar Convention on Wetlands (2018) Global Wetland Outlook: State of the World's Wetlands and their Services to People. Ramsar Convention Secretariat, Gland

29. Rosewarne PN (1981) Geohydrological investigation Breede Valley - between Wolsley and Brandvlei dam. DWAF Technical Report GH3186

30. Schulze RE, Lynch SD (2006) Annual Precipitation. WRC Report 1489/1/06. Water Research Commission, Pretoria

31. Schulze R, Angus G, Lynch S, Smithers J (1995) ACRU: Concepts and Structure. In: Hydrology and Agrohydrology: A Text to Accompany the ACRU 3.00 Agrohydrological Modelling System. Water Research Commission, Pretoria

32. Schuyt KD (2005) Economic consequences of wetland degradation for local populations in Africa. Ecol Econ 53:177-190

33. Seeliger L, De Clercq WP, Hoffman W, Cullis JDS, Horn AM, De Witt M (2018) Applying the water-energy-food nexus on farm profitability in the Middle Breede Catchment, South Africa. S Afr J Sci. 2018;114(11/12). https://doi.org/10.17159/sajs.2018/5062

34. Smithers J, Schulze R (1995) Background, Concepts and Application of the ACRU Agrohydrological Modelling System. Water Research Commission, Pretoria

35. Snaddon K, Dietrich J, Forsythe K, Turpie J (2018) Prioritisation of wetlands for water security in priority dam in priority dam catchments in the Western Cape Water Supply System catchments in the Western Cape Water Supply System. The Nature Conservancy. Retrieved October 2020, from https://sahris.sahra.org.za/sites/default/files/additionaldocs/Riviersonderend\%20Wetland\%20Rehabilitation\%20Plan.pdf

36. Turpie J (2003) The existence value of biodiversity in South Africa: how interest, experience, knowledge, income and perceived level of threat influence local willingness to pay. Ecol Econ 46:199-216

37. Turpie J, Forsythe K, Knowles A, Blignaut J, Letley G (2017) Mapping and valuation of South Africa's ecosystem services: A local perspective. Ecosystem Services

38. United States Geological Survey (2014) Digital Elevation - Shuttle Radar Topography Mission (SRTM) 1 Arc-Second Global s34_e019_1arc_v3.tif

39. Water Research Commission (2014) Livelihoods and Wetlands: Restoration of wetland social-ecological processes to sustain the ecosystem services necessary to support livelihoods

40. Western Cape Department of Agriculture (2018) An overview of the Brandvlei Project. Western Cape Department of Agriculture 41. Weitzman ML (2001) Gamma Discounting. Am Econ Rev 91(1):260-271

\section{Figures}




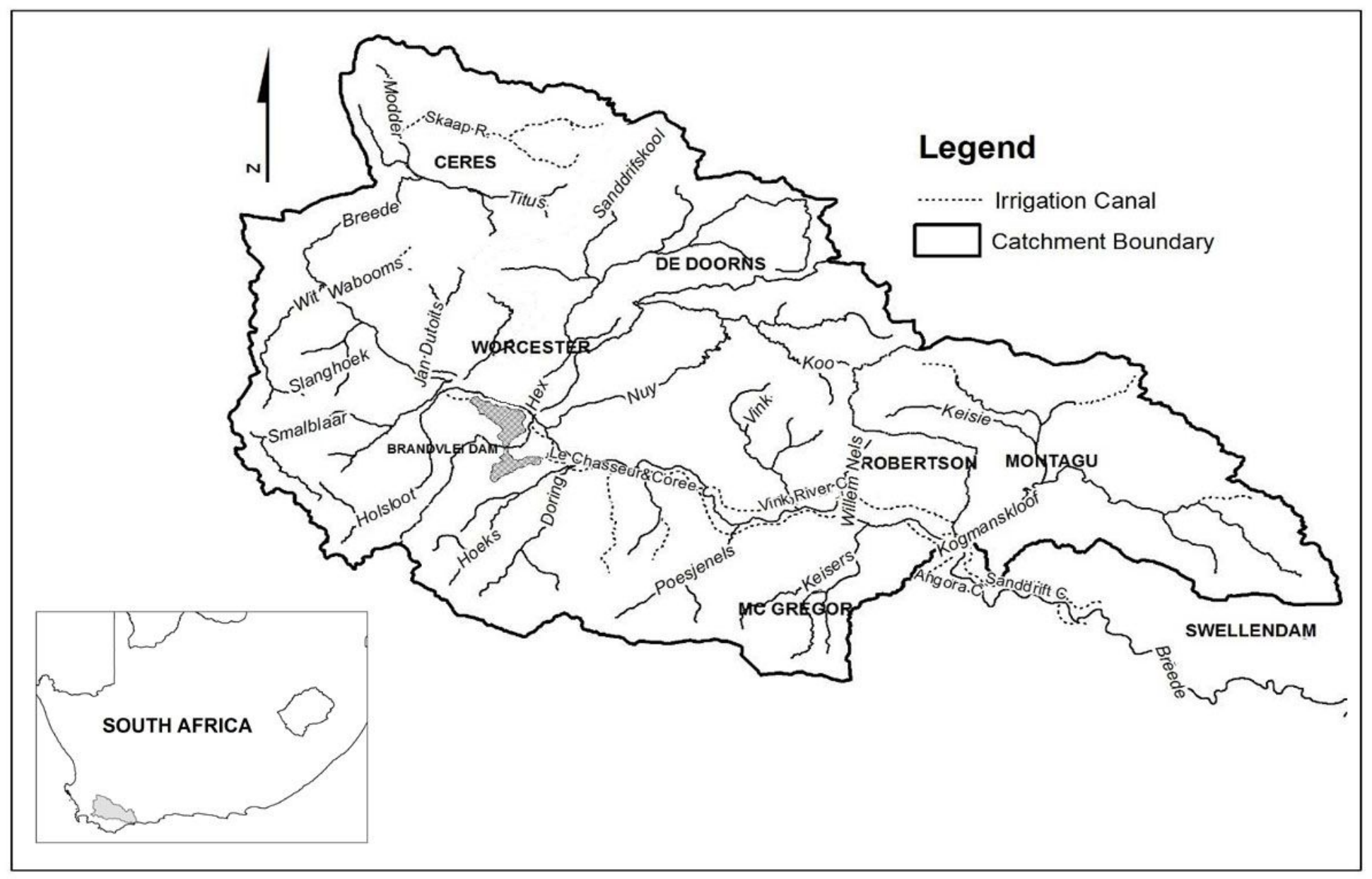

Figure 1

Map adapted from Kienzle and Flügel by DEA\&DP, Western Cape Government (Seeliger et al, 2018). Map showing the rivers of the Upper and Middle Breede River Catchment, with the insert giving the location of the Breede Catchment. Note: The designations employed and the presentation of the material on this map do not imply the expression of any opinion whatsoever on the part of Research Square concerning the legal status of any country, territory, city or area or of its authorities, or concerning the delimitation of its frontiers or boundaries. This map has been provided by the authors. 


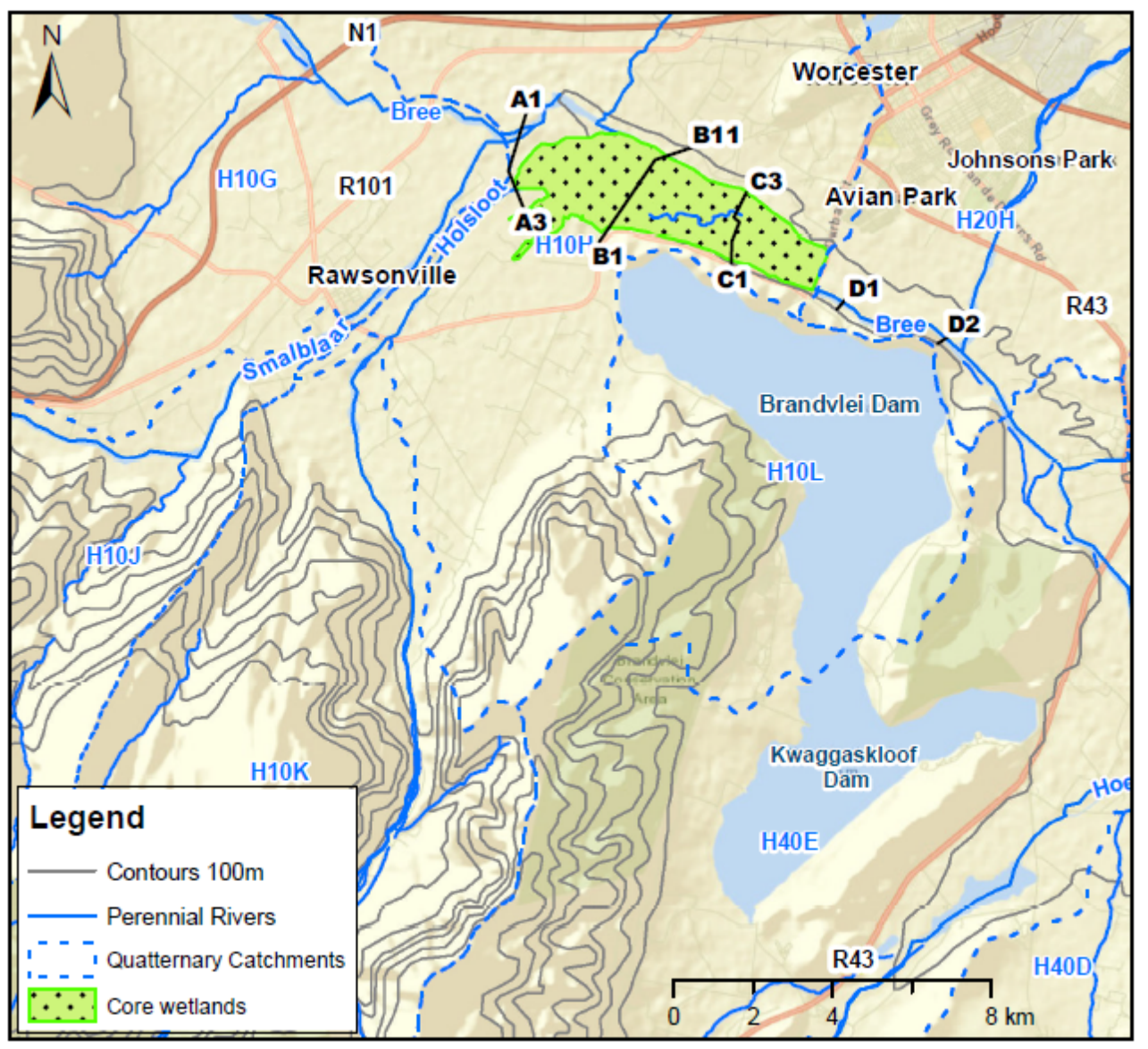

Figure 2

Map showing Papenkuils Wetland (dotted polygon), with transects along which soil profiles and vegetation were assessed, in quaternary catchment context. Note: The designations employed and the presentation of the material on this map do not imply the expression of any opinion whatsoever on the part of Research Square concerning the legal status of any country, territory, city or area or of its authorities, or concerning the delimitation of its frontiers or boundaries. This map has been provided by the authors. 


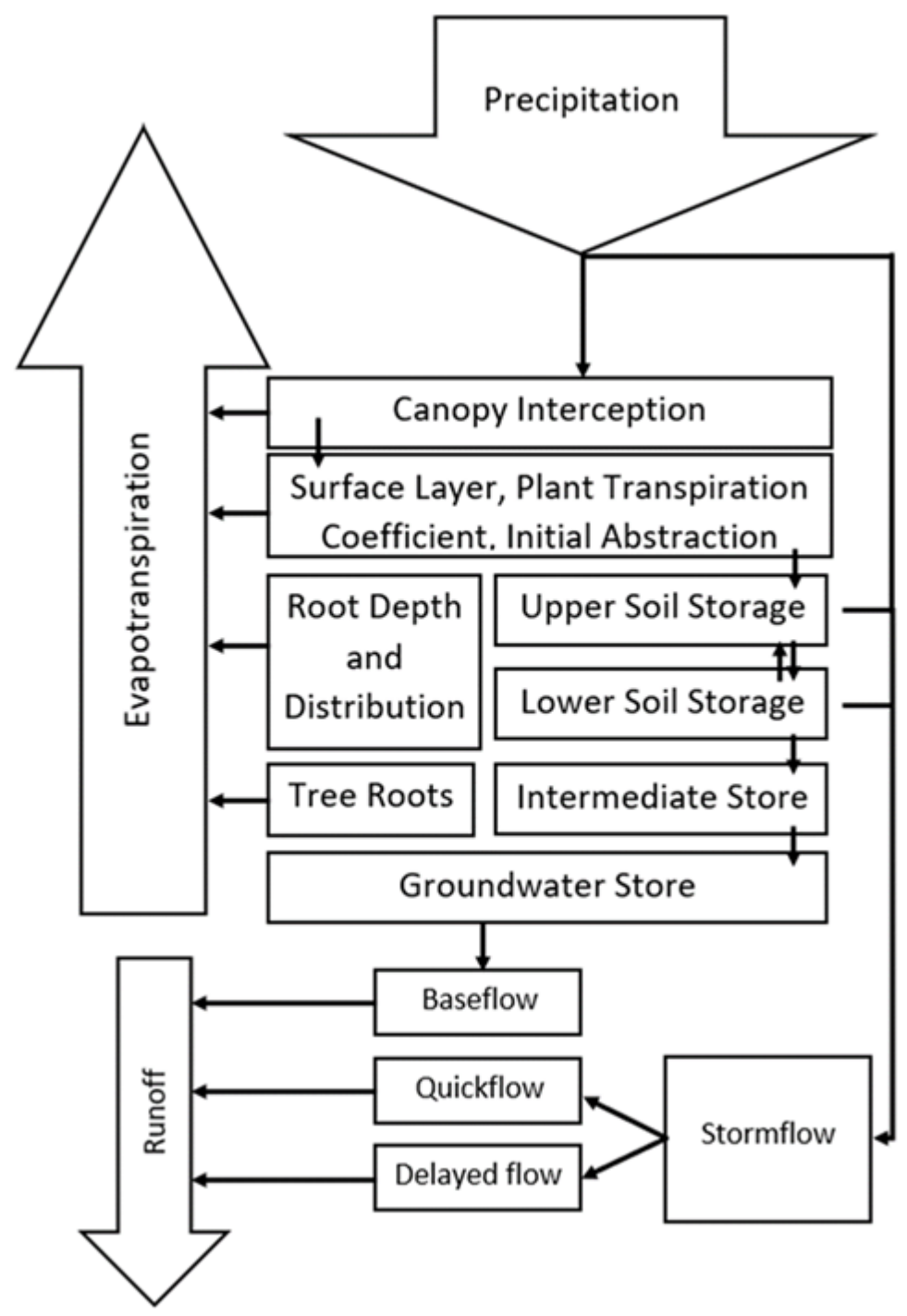

Figure 3

Soil water accounting of the ACRU model 


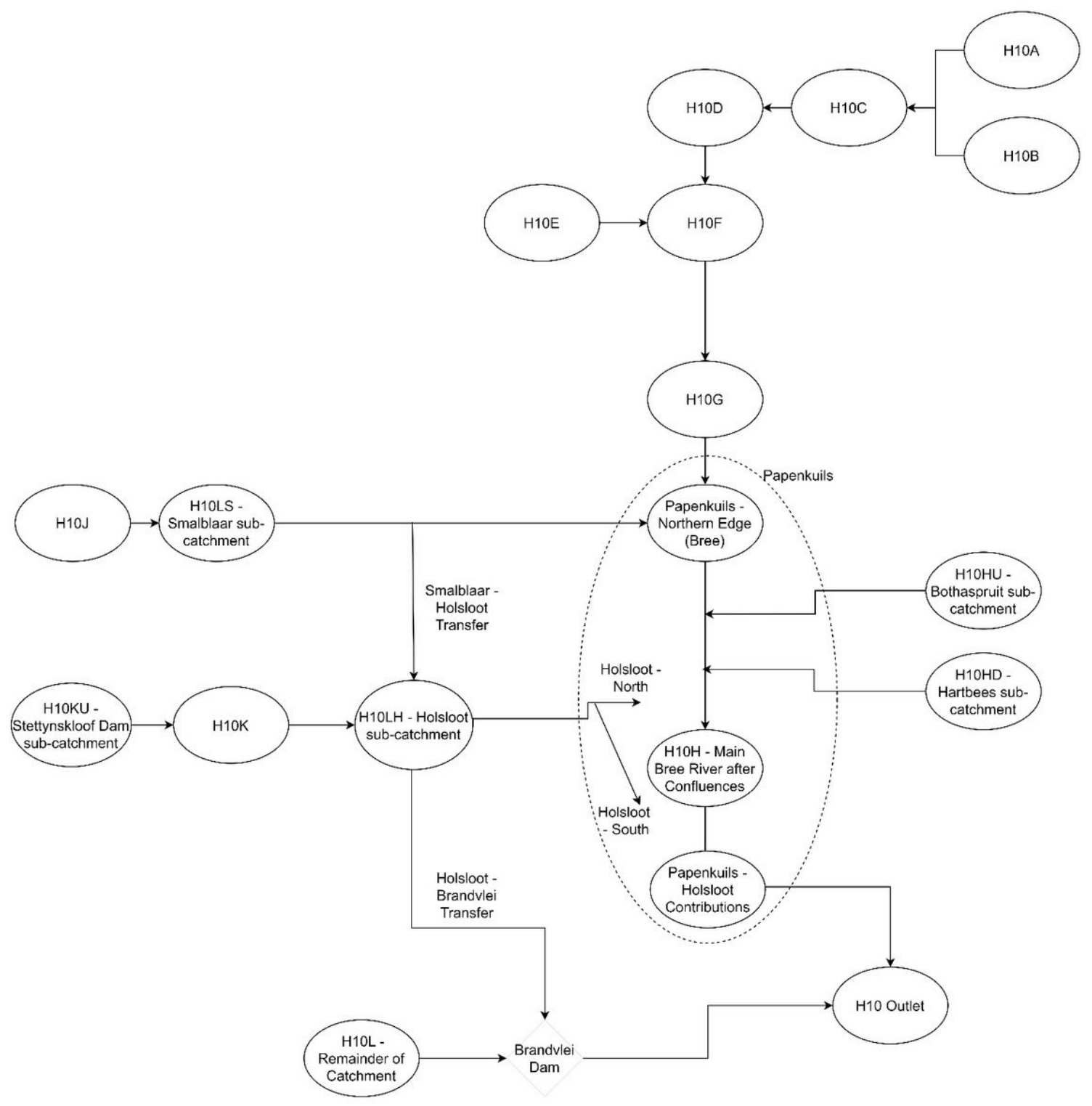

Figure 4

Flow routing through quaternary catchment $\mathrm{H} 10$, including diversions. 


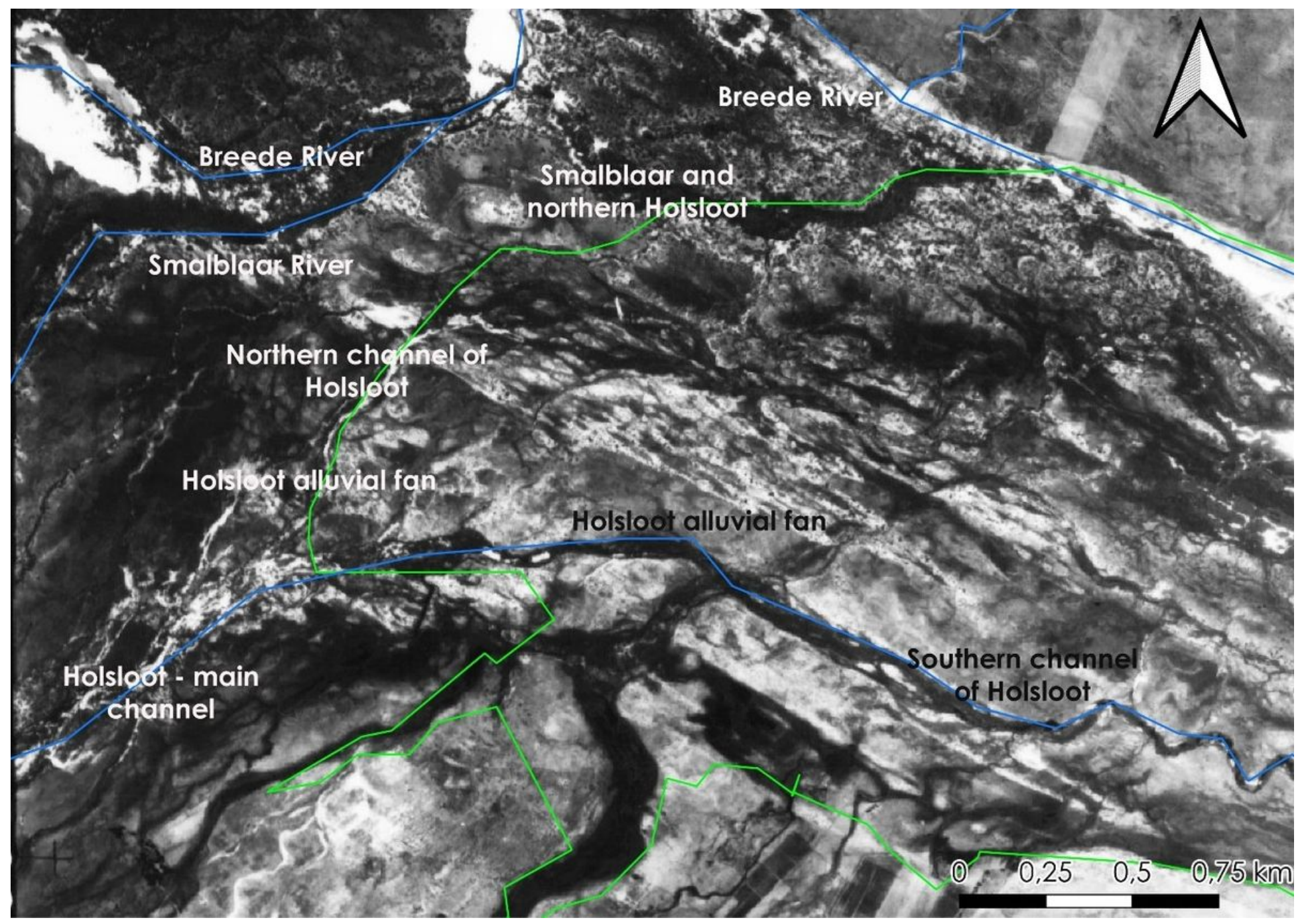

Figure 5

Aerial photographs showing the Papenkuils Wetland in 1948 Note: The designations employed and the presentation of the material on this map do not imply the expression of any opinion whatsoever on the part of Research Square concerning the legal status of any country, territory, city or area or of its authorities, or concerning the delimitation of its frontiers or boundaries. This map has been provided by the authors. 


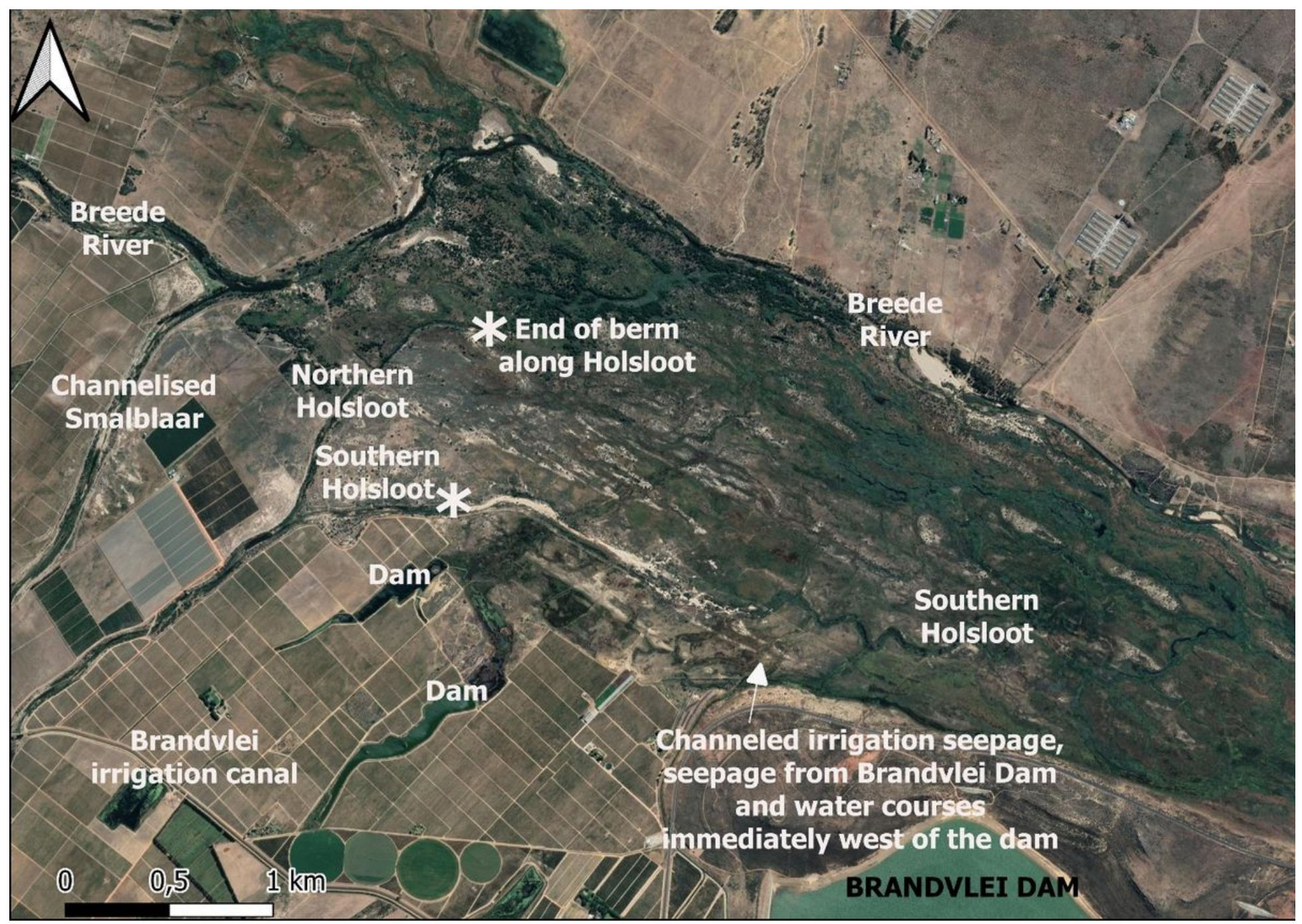

Figure 6

Aerial photographs showing a reduced wetland area in 2019 with the extension of agricultural lands. Note: The designations employed and the presentation of the material on this map do not imply the expression of any opinion whatsoever on the part of Research Square concerning the legal status of any country, territory, city or area or of its authorities, or concerning the delimitation of its frontiers or boundaries. This map has been provided by the authors. 